that equate bhakti with prapatti must first be ascertained, but the equation is wrong. The radical meanings of the two words are entirely different. $B h a j=$ adore, and pad $=$ go, or throw oneself at or on. The former (bhakti) requires active concentration on God on the part of the soul (adoration); whereas the latter (prapatti) simply demands resignation or unconditional capitulation, making no terms with God, but variegated by the two attitudes,(1) active, or aggressive; and (2) passive, or expectant, on the part of the soul. Rāmânuja's commentary on the Bhagavad-Gitta must be studied together with his Gadyatraya, before venturing on the remark made by Dr. Grierson that his commentary " is much to the same effect ". ${ }^{1}$

p. 568. Dr. Grierson's correction as to the meaning of Kaivalya is not complete. Kevalas might employ other means besides knowledge, $j \tilde{n} \bar{a} n a$, for their soul-realization. They might also resort to bhalcti, prapatti, or a cāaryabbhimanna, provided they resort to one or other of them as long as their goal is no other than that isolate state.

\title{
Note by Dr. Grierson on ThE above
}

Every student of Vaishnavism will be grateful to Govindacharya Svämin for the light thrown by him in the above notes on a most obscure branch of the subject. Space will not allow me to discuss them here, and I am ready to assume that, so far as doctrines of Southern Vaishnavism are concerned, the corrections are all justified. I therefore content myself with two remarks. As regards Ràmânuja's explanation of the word prapadyatē in Bhagavad-Gitta, vii, 19, it is translated "worships" by the Svāmin himself in his excellent English version of the poem with Rāmânuja's commentary. In the famous carama-ślōka (xviii, 66), which Vaishnavas look upon as

${ }^{1}$ See pp. $127 \mathrm{ff}$. of my Yatīndra-mata-dīpikā, just out. 
containing; the quintessence of the teaching of the poem, we have-

sarva-dharmān parityajya mäm èkam śaranam vraja "Renouncing all Dharmas, hold Me as thy sole refuge." On this Rāmânuja says: "All Dharmas = All the paths of righteousness inculcated in the Bhagavad-git $\bar{\alpha}$ as means to mōkşa, viz., karma-yōga, jñāna-yōga, and bhakti-yōga. Renouncing $=$ The practising of these means as modes of my worship, and in love; but entirely renouncing the fruit thereof (phala-tyāga), the personal ownership of the act (karma-tyāga), and personal authorship of act (kartrtvatyāga)." To this the Svāmin adds in a footnote: "Rāmânuja gives here the ordinary interpretation meaning bhakti, whereas a higher interpretation is prapatti." The rest of R.'s commentary on this verse is most instructive. It is plain that he considered that Kṛna instructed Arjuna to hold to Him, so as to enable Arjuna to "launch on bhakti-yogga", the only means of salvation. I have not seen the Gadyatraya, but it is plain that in his commentary to the Bhagavad-gīta Rāmânuja either ignored the modern prapatti altogether, or else considered it as included in the term "bhakti". This is, of course, not the only interpretation of the verse, which has probably had more treatises written concerning it than any other passage in the poem.

As regards the Kêvalas, see the Svāmin's description of them on p. 575 of the Journal for 1910. "These are the men who embark particularly upon the path of $j \tilde{n} \bar{a} n a$ yoga, which is chiefly the means to secure this coveted 'zoistic' state." The fact that they can also employ the other means is an interesting addition to our knowledge.

G. A. G.

CAMBERLeY.

December 5, 1911. 